\title{
Review \\ Current Management Options in Irvine-Gass Syndrome: A Systemized Review
}

\author{
Michał Orski ${ }^{1, *}$ and Maciej Gawęcki ${ }^{2}$ (1) \\ 1 Department of Ophthalmology, Ludwik Rydygier Memorial Hospital, Zlotej Jesieni 1, 31-826 Krakow, Poland \\ 2 Dobry Wzrok Ophthalmological Clinic, Kliniczna 1B/2, 80-402 Gdansk, Poland; maciej@gawecki.com \\ * Correspondence: orski.michal@gmail.com
}

Citation: Orski, M.; Gawęcki, M Current Management Options in Irvine-Gass Syndrome: A Systemized Review. J. Clin. Med. 2021, 10, 4375. https://doi.org/10.3390/jcm10194375

Academic Editors: María Isabel López-Gálvez and Giacinto Triolo

Received: 9 August 2021

Accepted: 18 September 2021

Published: 25 September 2021

Publisher's Note: MDPI stays neutral with regard to jurisdictional claims in published maps and institutional affiliations.

Copyright: (c) 2021 by the authors. Licensee MDPI, Basel, Switzerland. This article is an open access article distributed under the terms and conditions of the Creative Commons Attribution (CC BY) license (https:// creativecommons.org/licenses/by/ $4.0 /)$.

\begin{abstract}
Irvine-Gass syndrome (IGS) remains one of the most common complications following uneventful cataract surgery. In most cases, macular edema (ME) in IGS is benign, self-limiting, and resolves spontaneously without visual impairment; however, persistent edema and refractory cases may occur and potentially deteriorate visual function. Despite the relatively high prevalence of IGS, no solid management guidelines exist. We searched the PUBMED database for randomized clinical trials (RCT) or case series of at least 10 cases published since 2000 evaluating different treatment strategies in patients with cystoid macular edema (CME). The search revealed 28 papers that fulfilled the inclusion criteria with only seven RCTs. The scarceness of material makes it impossible to formulate strong recommendations for the treatment of IGS. Clinical practice and theoretical background support topical non-steroidal anti-inflammatory drugs (NSAIDs) as the first-line therapy. Invasive procedures, such as periocular steroids, intravitreal corticosteroids, and anti-vascular endothelial growth factor (anti-VEGF), are usually applied in prolonged or refractory cases. Results of novel applications of subthreshold micropulse laser (SML) are also promising and should be studied carefully in terms of the safety profile and cost effectiveness. Early initiation of invasive treatment for providing better functional results must be examined in further research.
\end{abstract}

Keywords: Irvine-Gass syndrome; cystoid macular edema; pseudophakic cystoid macular edema; NSAIDs corticosteroids; anti-VEGF; subthreshold diode micropulse

\section{Introduction}

Postoperative cystoid macular edema (CME) remains one of the most common complications of intraocular surgery. It is defined as a presence of intraretinal fluid (IF) spaces or central macular thickening (CMF) in optical coherence tomography (OCT) examination [1]. Irvine-Gass syndrome (IGS), sometimes named pseudophakic cystoid macular edema (PCME), is a cystoid macular edema that develops following uneventful cataract surgery. It was first described in 1953 by Irvine and studied using fluorescein angiography (FA) by Gass and Norton in 1966 [2,3]. Irvine-Gass syndrome remains the most common cause of decreased visual acuity after uneventful cataract surgery [4]. In most cases, no treatment is indicated as it resolves spontaneously, but persistent edema may also occur. Hunter et al. reported that $26.8 \%$ of eyes with pseudophakic CME did not recover $6 / 6$ vision [5].

The incidence of Irvine-Gass syndrome varies among studies and is highly dependent on the diagnostic criteria [6]. Diagnosis is made based on clinical findings along with visual impairment or based on the presence of FA leakage or IF on OCT scans. OCT shows cystic intraretinal spaces on high-resolution cross-sectional scans of the macula that can be accompanied by mild photoreceptors detachment [4,7]. The early phases of FA show macular leakage, and as FA helps to rule out other causes of macular edema (ME), it remains a gold standard as a diagnostic tool [8] when used with the OCT.

Clinically significant CME impairing patients' vision is found in 1-2\% of patients with its peak 6 weeks following surgery, but subclinical CME can be seen in about 30\% 
of patients in FA and up to $40 \%$ in OCT $[4,7,9]$. The risk factors include the presence of epiretinal membrane, history of uveitis, diabetes mellitus, and use of topical medications for glaucoma.

Several models have been considered, but multifactorial inflammatory origin seems to play a major role in the pathophysiology of Irvine-Gass syndrome. Surgical manipulation causes significant release of inflammatory mediators, including arachidonic acid, cytokines, lysozyme, and vascular endothelial growth factor (VEGF). The inflammatory cascade impairs the blood-aqueous and blood-retinal barriers and promotes vascular permeability $[10,11]$. Fluid accumulates in the outer plexiform and inner nuclear layers, creating cystic intraretinal spaces that coalesce to larger fluid cavities [6]. Prolonged CME may cause lamellar holes and persistent subretinal fluid.

To date, there are no uniform recommendations for the treatment of Irvine-Gass syndrome, and variable strategies are employed. This review aims to present the most important contemporary therapeutic strategies in IGS based on available modern literature.

\section{Material and Methods}

The PUBMED database was searched for a combination of phrases including the terms Irvin-Gass syndrome or pseudophakic cystoid edema and steroids, intravitreal steroids, periocular steroids, triamcinolone, sub-tenon triamcinolone, dexamethasone, OZURDEX ${ }^{\circledR}$, fluocinolone, non-steroidal anti-inflammatory drugs, anti-VEGF, aflibercept, ranibizumab, bevacizumab, carbonic anhydrase inhibitors, and acetazolamide.

Only randomized clinical trials or case series of at least 10 cases published since 2000 were included in the analysis and presented in the following tables. Reports using smaller samples were quoted only if larger studies were scarce or unavailable for the specific treatment modality.

The search revealed 28 articles, including 7 RCTs on the subject, that fulfilled inclusion criteria. Results were grouped according to the analyzed treatment modality.

If a treatment modality was not analyzed in a larger case series or RCT, results were presented descriptively.

\section{Results}

\subsection{Non-Steroidal Anti-Inflammatory Drugs (NSAID)}

The search revealed seven studies, including two RCTs, that met inclusion criteria analyzing the efficacy of NSAID eye drops in the treatment of IGS. The results of those studies are presented in Table 1. All the studies show functional and morphological improvement, although most patients still present some visual deficit at the end of the treatment. The latest studies favor topical nepafenac compared to other NSAID eye drops. No significant adverse events associated with the use of NSAIDs were reported in any of the studies. 
Table 1. Results of the studies analyzing the efficacy of NSAID in the treatment of IGS that involved at least 10 cases and were published since 2000.

\begin{tabular}{|c|c|c|c|c|c|}
\hline No & Study & No of Eyes & Duration of CME & Study Design & Results \\
\hline 1 & $\begin{array}{l}\text { Giarmoukakis } \\
\text { et al., } 2020[12]\end{array}$ & 21 eyes treated with TN $0.3 \%$ & $\begin{array}{l}\text { Acute }(<4 \text { months }) \text { and } \\
\text { chronic }(>4 \text { months })\end{array}$ & $\begin{array}{l}\text { Prospective, clinic-based, non-randomized } \\
\text { case-series }\end{array}$ & $\begin{array}{c}\text { BCVA improvement from } 0.49 \pm 0.36 \text { logMAR to } \\
0.36 \pm 0.42 \text { logMAR at the last follow-up visit } \\
(p<0.005) \text {. CRT decreased from } 450.40 \pm 90.74 \mu \mathrm{m} \text { at } \\
\text { baseline to } 354.60 \pm 81.49 \mu \mathrm{m}(p<0.05)\end{array}$ \\
\hline 2 & $\begin{array}{l}\text { Guclu et al., } \\
2019 \text { [13] }\end{array}$ & $\begin{array}{l}62 \\
\text { The IVD group included } 32 \text { eyes, } \\
\text { and the TN group included } 30 \text { eyes }\end{array}$ & 2 months & $\begin{array}{c}\text { Retrospective; two arms: } \\
\text { IVD: } 32 \text { patients, } \\
\text { TN } 0.1 \%: 30 \text { patients; changes in BCVA, CMT at } \\
\text { baseline, } 1 \text { month, } 3 \text { months, } 6 \text { months }\end{array}$ & $\begin{array}{c}\text { Results at } 6 \text { months: } \\
\text { BCVA change in ETDRS letters for IVD from } 25 \pm 11.8 \\
\text { to } 49.3 \pm 6.8 \text { versus } 20.9 \pm 9.3 \text { to } 32.9 \pm 7.3 \text { for TN; } \\
\text { CMT reduction from } 522.7 \pm 120.7 \mu \mathrm{m} \text { to } \\
266.1 \pm 53.4 \mu \mathrm{m} \text { for IVD versus } 501.2 \pm 104.2 \mu \mathrm{m} \text { to } \\
\quad 364.9 \pm 56.3 \mu \mathrm{m} \text { ) for TN; } \\
\text { statistically significantly better improvements for IVD } \\
\text { than TN }\end{array}$ \\
\hline 3 & $\begin{array}{l}\text { Sengupta et al., } \\
2018[14]\end{array}$ & 69 & Acute, precise duratio not defined & $\begin{array}{l}\text { Retrospective; combined topical prednisolone QID } \\
\text { for } 6 \text { weeks and TN for at least } 6 \text { weeks QID; } \\
\text { evaluation of effect at } 6 \text { weeks; success criterion: } \\
\text { BCVA 6/9 and CMT } £ 300 \mathrm{~mm} \text {; definition of any } \\
\text { success: anything less than success and reduction of } \\
\text { CMT by } 150 \mathrm{~mm}\end{array}$ & $\begin{array}{l}\text { Success achieved in } 37 \text { eyes ( } 54 \%) \text { and any success in } \\
55 \text { eyes ( } 80 \%) \text { at } 6 \text { weeks }\end{array}$ \\
\hline 4 & $\begin{array}{l}\text { Yuksel et al., } \\
2017 \text { [15] }\end{array}$ & $\begin{array}{l}24 \mathrm{TA} \text { arm } \\
24 \mathrm{TN} \text { arm }\end{array}$ & $\begin{array}{l}\text { Mean duration } 4.8 \pm 5.0 \text { weeks for } \\
\text { TA and } 4.5 \pm 3.1 \text { weeks for TN }\end{array}$ & $\begin{array}{c}\text { Prospective; two arms: TA and TN; changes in CMT } \\
\text { and BCVA at } 6 \text { months }\end{array}$ & $\begin{array}{c}\text { Significant reduction of CMT and improvement of } \\
\text { BCVA in both groups; BCVA change from } 0.99 \pm 0.62 \\
\text { logMAR to } 0.63 \pm 0.74 \text { for TA and from } 0.84 \pm 0.65 \text { to } \\
0.37 \pm 0.48 \text { for TN } \\
\text { reduction of CMT from } 513.3 \text { to } 318.9 \mathrm{~mm} \text { in TA arm } \\
\text { and from } 483.7 \text { to } 278.0 \mathrm{~mm} \text { in TN arm; BCVA } \\
\text { statistically better improvement in the TN arm }\end{array}$ \\
\hline 5 & $\begin{array}{l}\text { Warren et al., } \\
2010[16]\end{array}$ & 39 & Chronic 6 months, mean 9.4 months & $\begin{array}{l}\text { RCT; evaluation of the effect of adding topical } \\
\text { NSAID in IGS; } \\
\text { Design: IVT and IVB at study entry; IVB repeated } \\
\text { after } 1 \text { month; afterward randomization to topical } \\
\text { diclofenac } 0.1 \% \text { or ketorolac } 0.4 \% \text { or nepafenac } 0.1 \% \\
\text { or bromfenac } 0.09 \% \text { or placebo for } 16 \text { weeks; } \\
\text { evaluation at } 16 \text { weeks }\end{array}$ & $\begin{array}{l}\text { Significant reduction of CMT compared with placebo } \\
\text { for TN and topical bromfenac; improvement of BCVA } \\
\text { for nepafenac only (by 19\%) }\end{array}$ \\
\hline
\end{tabular}


Table 1. Cont.

No Study No of Eyes
Retrospective multicenter review of $22 \mathrm{CME}$ cases treated with TN $0.1 \%$ (six with concomitant prednisolone acetate $1 \%$ ); duration of the follow up from 6 weeks to 6 months uveitic CME including 13 with

uveitic CME, including 13 with

(20 patients) treated with TN $0.1 \%$ )
Acute IGS $<6$ months
Chronic IGS $>6$ months
Results

BCVA improvement in 2 acute IGS

BCVA improve to 0.18 logMAR and from $0.3 \log$ MAR to $0.14 \log$ MAR)

CRT reduction from 448 to $211 \mathrm{~mm}$ and from 306 to $284 \mathrm{~mm}$. Morphological improvement in the third acute case: reduction of CMT from 380 to $236 \mathrm{~mm}$, but no BCVA change due to retinal degeneration;

mean BCVA improvement in the chronic group from $0.63 \pm 0.33 \log \mathrm{MAR}$ to $0.30 \pm 0.16 \log \mathrm{MAR}$ and mean CMT reduction from $451 \pm 145.7$ to $273 \pm 80.8 \mathrm{~mm}$

\section{BCVA change}

ketorolac: from $20 / 160 \pm 75.8$ to $20 / 58 \pm 94.1$ diclofenac: from $20 / 173+94$ to $20 / 49+56.8$ Red), ketorola $14(88 \%)$; elimination of CME $(89 \%)$, ketolac $14(88 \%)$; elmination of CME at no significant difference between the drugs
no

$7 \quad$ Rho 2003 [18] $\quad \begin{aligned} & 34: \\ & \text { Diclofenac } 18 \\ & \text { Ketorolac } 16\end{aligned}$

\section{Acute:
$4.2 \pm 1.4$ months for ketorolac group and $4.0 \pm 1.4$ months for} diclofenac group
Randomized prospective; evaluation of effects of topical diclofenac sodium $0.1 \%$ versus ketorolac at 26 weeks

o significant difference between the drugs

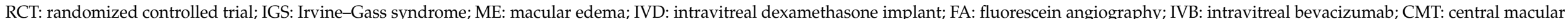
thickness; TA: triamcinolone acetonide; TN: topical nepafenac; BCVA: best-corrected visual acuity; CME: cystoid macular edema; QID-quater in die 


\subsection{Carbonic Anhydrase Inhibitors (CAI)}

The search revealed only 2 studies that analyzed the additional effect of 250-500 mg of oral acetazolamide compared to that from topical NSAIDs or corticosteroids alone (Table 2). Both papers present better functional and morphological results of combined NSAID with or without corticosteroid plus CAI. Both papers present better functional and morphological results of NSAID combined with CAI. No data evaluating the potential role of topical CAIs were found.

Table 2. Results of the studies analyzing the efficacy of CAI in the treatment of IGS that involved at least 10 cases and were published since 2000 .

\begin{tabular}{|c|c|c|c|c|c|}
\hline No & Study & No of Eyes & Duration of CME & Study Design & Results \\
\hline 1 & $\begin{array}{l}\text { Curkovic et al., } \\
2005 \text { [19] }\end{array}$ & $\begin{array}{c}14 \\
7-0.1 \% \text { topical dexamethason }+ \\
\text { topical flurbiprofen (group 1) } \\
7-0.1 \% \text { topical dexamethason }+ \\
\text { topical flurbiprofen plus } \\
\text { acetazolamide } 250 \mathrm{mg} \mathrm{3 \times} \\
\text { (group 2) }\end{array}$ & Not defined & $\begin{array}{l}\text { RCT, the efficacy of oral } \\
\text { acetazolamide of } \\
250 \text { mg TID in addition } \\
\text { to topical } \\
\text { dexamethasone and } \\
\text { flurbiprofen }\end{array}$ & $\begin{array}{l}\text { Complete resolution of CME in } 86 \% \text { of eyes } \\
\text { receiving acetazolamide (plus the topical } \\
\text { NSAID-steroid combination) vs. } 29 \% \text { in the } \\
\text { control group who received topical } \\
\text { dexamethasone and flurbiprofen alone } \\
\text { BCVA change significantly better in group } 2 \\
\text { from } 0.32 \pm 0.1 \text { to } 0.67 \pm 0.1 \text { versus } 0.34 \pm 0.12 \\
\text { to } 0.53 \pm 0.14 \text { in group } 1 \text { (Snellen fraction) }\end{array}$ \\
\hline 2 & $\begin{array}{l}\text { Catier et al., } \\
2005 \text { [20] }\end{array}$ & 16 & 5 months & $\begin{array}{l}\text { Retrospective review } \\
\quad 250-500 \mathrm{mg} \text { of } \\
\text { acetazolamide per day } \\
\text { associated with topical } \\
\text { NSAID or steroids }\end{array}$ & $\begin{array}{c}\text { Mean improvement of BCVA from } 20 / 100 \\
(0.7 \pm 0.28 \text { Log MAR) to } 20 / 40(+0.3 \pm 0.2 \mathrm{Log} \\
\text { MAR) and reduction of CMT from } \\
599.67 \pm 174.17 \mathrm{~mm} \text { to } 264.69 \pm 106.59 \mathrm{~mm} ; \\
\text { complete resolution in } 87.5 \% \text { cases and in } 100 \% \\
\text { of cases treated by a combination of } \\
\text { acetazolamide, NSAIDs and steroids }\end{array}$ \\
\hline
\end{tabular}

CT: randomized controlled trial; IGS: Irvine-Gass syndrome; CMT: central macular thickness; NSAID: non-steroidal anti-inflammatory drugs; BCVA: best-corrected visual acuity; CME: cystoid macular edema; mo—month; TID—ter in die.

\subsection{Corticosteroids}

\subsubsection{Topical Corticosteroids}

The search revealed only two studies that analyzed the additional effect of topical corticosteroids compared to NSAIDs alone. The results are presented in Table 3 and do not provide an unequivocal answer whether any additional effect exists: possible benefits are advocated in the Heier et al. study [21] but not confirmed in the study by Singal et al. [22].

Table 3. Results of the studies analyzing the efficacy of the addition of topical corticosteroids to NSAID in the treatment of IGS that involved at least 10 cases and were published since 2000.

\begin{tabular}{|c|c|c|c|c|c|}
\hline No & Study & No of Eyes & Duration of CME & Study Design & Results \\
\hline 1 & $\begin{array}{l}\text { Heier et al., } \\
2000[21]\end{array}$ & $\begin{array}{l}28 \text { (26 completed the } \\
\text { study) }\end{array}$ & $\begin{array}{l}\text { Acute: } 21-90 \text { days } \\
\text { after surgery }\end{array}$ & $\begin{array}{l}\text { RCT, patients randomized to topical } \\
\text { therapy with ketorolac (group K), } \\
\text { prednisolone (group P), or ketorolac and } \\
\text { prednisolone combination therapy (group } \\
\text { C) QID. Follow up, } 3 \text { months. }\end{array}$ & $\begin{array}{c}\text { BCVA improvements (Snellen lines): } 1.6 \\
\text { in group K, } 1.21 \text { in group P, and } 3.8 \text { in } \\
\text { group C. } \\
\text { Treatment of acute, visually significant } \\
\text { pseudophakic CME with ketorolac and } \\
\text { prednisolone combination therapy } \\
\text { appears to offer benefits over } \\
\text { monotherapy with either agent alone }\end{array}$ \\
\hline 2 & $\begin{array}{l}\text { Singal et al., } \\
2004[22]\end{array}$ & $\begin{array}{c}10 \\
\text { Ketorolac: } 4 \\
\text { Ketorolac and } \\
\text { tromethamine: } 6\end{array}$ & 6 weeks and longer & $\begin{array}{c}\text { RCT: prospective double-masked } \\
\text { randomized controlled trial. } \\
10 \text { patients were randomly assigned to } \\
\text { receive either } 0.5 \% \text { ketorolac tromethamine } \\
\text { plus placebo or } 0.5 \% \text { ketorolac } \\
\text { tromethamine plus } 1 \% \text { prednisolone } \\
\text { acetate; follow up, } 90 \text { days }\end{array}$ & $\begin{array}{l}\text { No statistically significant difference } \\
\text { was found in the outcome between } \\
\text { patients who received ketorolac and } \\
\text { those who received ketorolac plus } \\
\text { prednisolone for acute or chronic CME }\end{array}$ \\
\hline
\end{tabular}

RCT: randomized controlled trial; IGS: Irvine-Gass syndrome; CMT: central macular thickness NSAID: non-steroidal anti-inflammatory drugs; BCVA: best-corrected visual acuity; CME: cystoid macular edema.

\subsubsection{Periocular Corticosteroids}

The search revealed only three papers fulfilling the search criteria. The results of these studies are presented in Table 4. All are retrospective analyses and present significant improvement of both macular morphology and BCVA after sub-tenon injection of triamcinolone acetonide (STT) in IGS patients. A study by Kuley et al. [23] compared the effects 
of STT and IVT in a large sample but did not show a significant difference in final effect depending on the drug administration route.

Table 4. Results of the studies analyzing the efficacy of periocular corticosteroids in the treatment of IGS that involved at least 10 cases and were published since 2000 .

\begin{tabular}{|c|c|c|c|c|c|}
\hline No & Study & No of Eyes & Duration of CME & Study Design & Results \\
\hline 1 & Kuley et al., 2021 [23] & $\begin{array}{l}50 \mathrm{STT} \\
45 \mathrm{IVT}\end{array}$ & Not stated & $\begin{array}{l}\text { Retrospective; } \\
\text { comparison of } \\
\text { resolution of IGS in two } \\
\text { arms: } 2 \text { mg IVT or } \\
40 \text { mg STT at } 1,3 \text {, and } \\
6 \text { months }\end{array}$ & $\begin{array}{l}\text { Insignificant difference in BCVA improvement: } 2.3 \text { lines } \\
\text { in the IVT group and } 2.4 \text { lines in the STT group; CMT } \\
\text { reduction was significantly better in the IVT group at } \\
\text { month } 1(255 \mathrm{~mm} \text { vs. } 187 \mathrm{~mm}) \text {, but the difference was } \\
\text { not present at month } 3(214 \mathrm{~mm} \text { vs. } 212 \mathrm{~mm}) \text { and month } \\
6(176 \mathrm{~mm} \text { vs. } 207 \mathrm{~mm}) \text {; ocular hypertension managed by } \\
\text { topical therapy in } 7 \% \text { of eyes in the IVT group and } 12 \% \\
\text { of eyes in the STT group }\end{array}$ \\
\hline 2 & Erden et al., 2019 [24] & 21 & Not stated & $\begin{array}{l}\text { Retrospective; patients } \\
\text { treatment naïve; } \\
\text { injection of } 40 \text { mg of } \\
\text { STT; minimum follow } \\
\text { up } 6 \text { months }\end{array}$ & $\begin{array}{l}\text { Significant improvement of mean BCVA from } 0.71 \pm 0.23 \\
\text { logMAR to } 0.19 \pm 0.06 \log M A R \text { and significant reduction } \\
\text { of CMT from } 431 \pm 136 \mathrm{~mm} \text { to } 299 \pm 66 \mathrm{~mm} \text { at } 6 \text { months }\end{array}$ \\
\hline 3 & Tsai et al., 2018 [25] & 17 & $\begin{array}{c}57.9 \pm 50.1 \text { days } \\
\text { (range: } 21-178 \text { days). }\end{array}$ & $\begin{array}{l}\text { Retrospective; } 40 \mathrm{mg} \text { of } \\
\text { STT; evaluation of } \\
\text { BCVA and CMT at } 1 \\
\text { and } 3 \text { months }\end{array}$ & $\begin{array}{l}\text { Change of logMAR BCVA from baseline } 0.75 \pm 0.23 \text { to } \\
0.50 \pm 0.20 \text { at month } 1 \text { and } 0.40 \pm 0.20 \text { at month } 3 \text {. } \\
\text { Change of CMT from baseline } 446 \pm 107 \mathrm{~mm} \text { to } \\
354 \pm 90 \mathrm{~mm} \text { at month } 1 \text { and } 300 \pm 58 \mathrm{~mm} \text { at month } 3 \text {. } \\
\text { Insignificant rise of IOP }<21 \mathrm{~mm} \mathrm{Hg}\end{array}$ \\
\hline
\end{tabular}

RCT: randomized controlled trial; IGS: Irvine-Gass syndrome; ME: macular edema; IVD: intravitreal dexamethasone implant; FA: fluorescein angiography; IVB: intravitreal bevacizumab; IVT—intravitreal triamcinolone; CMT: central macular thickness; TA: triamcinolone acetonide; STT: sub-tenon triamcinolone; IOP: intraocular pressure; BCVA: best-corrected visual acuity.

\subsubsection{Intravitreal Corticosteroid}

In the search, we found eight larger reports published since $2000^{t}$ that are presented in Table 5. The search revealed only two larger studies evaluating the efficacy of IVT in IGS (listed in Table 5). However, randomized controlled trials of IVT are missing. In addition, transient effects and the need for repeated injections remain a challenge [26]. Most high-quality studies on the use of intravitreal corticosteroids in IGS are focused on the use of an intravitreal dexamethasone implant (IVD) of 700 micrograms, commercially used under the name OZURDEX ${ }^{\circledR}$ (five studies). One study associated the results of IGS treatment with either IVD, IVT, or anti-VEGF to the time point of initiation of treatment [27]. Most of the patients were treated with IVD. All the listed studies demonstrated significant letter gains after intravitreal corticosteroid therapy without serious adverse events. Few cases of intraocular pressure rise were controlled with topical anti-glaucoma medication. The study by Sharma and his group showed that early initiation of intravitreal treatment in IGS provides better functional results [27]. The use of the a fluocinolone implant was not tested on a larger sample; however, available reports confirm its efficacy in the resolution of IGS in recurrent cases [28].

Table 5. Results of the studies analyzing the efficacy of intravitreal corticosteroids in the treatment of IGS that involved at least 10 cases and were published since 2000 .

\begin{tabular}{|c|c|c|c|c|c|}
\hline No & Study & No of Eyes & $\begin{array}{l}\text { Duration of CME } \\
\text { (Months) }\end{array}$ & Study Design & Results \\
\hline 1 & Sharma et al., 2020 [27] & 79 & Less than 14 weeks & $\begin{array}{l}\text { Retrospective; } \\
\text { evaluation of the effect } \\
\text { of IVD or IVT or } \\
\text { anti-VEGF in IGS; } \\
\text { evaluation at } 12 \text { months }\end{array}$ & $\begin{array}{c}\text { IVD in } 73.4 \% \text { of eyes as initial therapy; switch from } \\
\text { anti-VEGF to dexamethasone in } 54.5 \% \text { of cases; } \\
\text { BCVA gain and CMT reduction } 16.7 \pm 12.9 \text { letters and } \\
336.7 \pm 191.7 \mathrm{~mm} \text { in patients treated within } 4 \text { weeks } \\
\text { from diagnosis versus } 5.2 \pm 9.2 \text { letters and } \\
160.1 \pm 153.1 \mathrm{~mm} \text { for patients treated after } 14 \text { weeks } \\
\text { from diagnosis; } \\
\text { IOP rise in } 3 \text { patients after IVD controlled with } \\
\text { topical medications }\end{array}$ \\
\hline 2 & Altintas et al., 2019 [29] & 10 & Minimum 3 months & $\begin{array}{l}\text { Retrospective; IGS } \\
\text { resistant to topical } \\
\text { treatment and IVB; } \\
\text { implantation of IVD }\end{array}$ & $\begin{array}{c}\text { Significant improvement of mean BCVA from } \\
0.69 \pm 0.19 \text { logMAR to } 0.19 \pm 0.05 \text { logMAR and } \\
\text { significant reduction of mean CMT from } \\
476.13 \pm 135.13 \text { mm to } 268.38 \pm 31.35 \mathrm{~mm} \text {; mean } \\
\text { number of IVD: } 1.44 \pm 0.89\end{array}$ \\
\hline
\end{tabular}


Table 5. Cont.

\begin{tabular}{|c|c|c|c|c|c|}
\hline No & Study & No of Eyes & $\begin{array}{l}\text { Duration of CME } \\
\text { (Months) }\end{array}$ & Study Design & Results \\
\hline 3 & Bellocq et al., 2017 [30] & 100 & Mean 4.8 months & $\begin{array}{c}\text { Retrospective } \\
\text { multicenter national } \\
\text { case series of } 100 \text { eyes } \\
\text { receiving IVD for } \\
\text { post-surgical macular } \\
\text { edema }\end{array}$ & $\begin{array}{c}\text { Mean improvement in BCVA was } 9.6 \pm 10.6 \text { letters at } \\
\text { month } 6 \text { and } 10.3 \pm 10.7 \text { letters at month } 12 \text {; BCVA } \\
\text { gains of } 15 \text { or more letters noted in } 32.5 \% \text { cases and } \\
37.5 \% \text { cases at months } 6 \text { and } 12 \text {, respectively; mean } \\
\text { reduction in CSMT of } 135.2 \text { mm and } 160.9 \text { mm at } \\
\text { months } 6 \text { and } 12 \text {, respectively } \\
\text { 37\% of patients required only one IVD during the first } \\
\text { year and experienced no recurrence of the macular } \\
\text { edema in a follow-up period of greater than } 1 \text { year }\end{array}$ \\
\hline 4 & Mayer et al., 2015 [31] & 23 & $\begin{array}{l}\text { Mean } 5.4 \text { months } \\
\quad \text { (range 2-8) }\end{array}$ & $\begin{array}{l}\text { Prospective; treatment } \\
\text { with IVD; evaluation of } \\
\text { BCVA and CMT at } \\
12 \text { months }\end{array}$ & $\begin{array}{l}\text { Significant improvement of mean BCVA from } \\
30.2 \pm 4.3 \text { letters to } 50.4 \pm 4.9 \text { letters and decrease of } \\
\text { CMT from } 520.8 \pm 71.4 \mathrm{~mm} \text { to } 232.7 \pm 26.6 \mathrm{~mm} \text {; no } \\
\text { relevant adverse effects were noted }\end{array}$ \\
\hline 5 & Zamil 2015 [32] & 11 & $\begin{array}{l}\text { Mean } 7.7 \text { months } \\
\quad \text { (range 6-10) }\end{array}$ & $\begin{array}{l}\text { Retrospective; single } \\
\text { IVD; evaluation at } \\
6 \text { months }\end{array}$ & $\begin{array}{l}\text { Significant mean BCVA improvement from } \\
0.58 \pm 0.17 \text { logMAR to } 0.21 \pm 0.15 \text { logMAR and } \\
\text { reduction of mean CMT from } 513.8 \mathrm{~mm} \text { to } 308.0 \mathrm{~mm} ; \\
\text { no adverse events were noted }\end{array}$ \\
\hline 6 & Sevim et al., 2012 [33] & $\begin{array}{l}\text { IVT: 20; } \\
\text { PPV: } 19\end{array}$ & 6 months and longer & $\begin{array}{c}\text { Retrospective; } \\
\text { comparison of BCVA } \\
\text { and CMT in two arms: } \\
\text { IVT and PPV; } \\
\text { evaluation at } 12 \text { months }\end{array}$ & $\begin{array}{c}\text { BCVA change at } 12 \text { months: IVT: from } 0.75 \pm 0.23 \\
\text { logMAR to } 0.45 \pm 0.23 \text { logMAR } \\
\text { PPV: } 0.78 \pm 0.25 \text { logMAR to } 0.51 \pm 0.21 \log \mathrm{MAR} ; \\
\text { CMT change at } 12 \text { months: } \\
\text { IVT: } 536.00 \pm 52.04 \mathrm{~mm} \text { to } 313.15 \pm 44.30 \mathrm{~mm} \\
\text { PPV: } 524.05 \pm 63.49 \mathrm{~mm} \text { to } 326.31 \pm 72.88 \mathrm{~mm} ; \\
\text { significant improvement of BCVA and reduction of } \\
\text { CMT at } 12 \text { months; no significant difference between } \\
\text { the arms at } 12 \text { months; temporary }\end{array}$ \\
\hline 7 & Williams et al., 2009 [34] & 41 & 90 days and longer & $\begin{array}{l}\text { RCT; CME secondary to } \\
\text { uveitis or IGS, } \\
\text { persistent } 90 \text { days; } \\
\text { Three arms } \\
\text { IVD }(700 \mathrm{mg}) \text { or } \\
\text { intravitreal } \\
\text { dexamethasone } 350 \mathrm{mg} \\
\text { or observation }\end{array}$ & $\begin{array}{l}\text { Improvement of at least } 10 \text { ETDRS letters at day } 90 \text { : } \\
41.7 \% \text { in } 350 \mathrm{mg} \text { group } \\
53.8 \% \text { in } 700 \mathrm{mg} \text { group } \\
7.1 \% \text { in observed group; } \\
\text { significant reduction of leakage on FA in } \\
\text { treated patients; } \\
\text { intraocular pressure rise of } 10 \mathrm{~mm} \mathrm{Hg} \text { or more in } 5 \text { of } \\
13 \text { patients in the } 700 \mathrm{mg} \text { group and in } 1 \text { of } 12 \text { patients } \\
\text { in the } 350 \mathrm{mg} \text { group, controlled by topical medication }\end{array}$ \\
\hline 8 & $\begin{array}{l}\text { Koutsandrea et al., } \\
2007[35]\end{array}$ & 14 & Longer than 6 months & $\begin{array}{l}\text { Retrospective; } 14 \text { eyes } \\
\text { treated with IVT; follow } \\
\text { up } 12 \text { months }\end{array}$ & $\begin{array}{c}\text { Improvement of BCVA from mean } 2.22 \pm 0.16 \text { to } \\
0.36 \pm 0.24 \text { (decimal values) at } 12 \text { months; } \\
\text { improvement of BCVA in } 11 \text { cases, stable in } 2 \text { cases } \\
\text { and worsening in } 1 \text { case; reduction of CMT from mean } \\
434.93 \text { to } 402.79 \pm 162.22 \text { mm; reduction of CMT in } 11 \\
\text { cases and increase in } 3 \text { cases; increase in mf-ERG } \\
\text { values; minor increase in IOP; topical IOP-lowering } \\
\text { drops in } 3 \text { patients }\end{array}$ \\
\hline
\end{tabular}

RCT: randomized controlled trial; IGS: Irvine-Gass syndrome; CME: cystoid macular edema; IVD: intravitreal dexamethasone implant (700 mg); IVT: intravitreal triamcinolone; PPV: pars plana vitrectomy; FA: fluorescein angiography; IVB: intravitreal bevacizumab; CMT: central macular thickness; mf-ERG: multifocal electroretinogram; BCVA: best-corrected visual acuity.

\subsection{Anti-VEGF}

The search revealed six larger studies analyzing the effects of different anti-VEGF medications in the treatment of IGS: four studies employed intravitreal bevacizumab (IVB), one dedicated to intravitreal ranibizumab (IVR) and one compared the efficacy of the available three agents: aflibercept, ranibizumab, and bevacizumab. Results of those studies are presented in Table 6 and show significant visual and morphological improvements for all the available anti-VEGF medications without serious adverse effects. Intravitreal aflibercept (IVA), a more recent anti-VEGF agent, has been tried in the treatment of IGS, but except for one comparative study listed in Table 6, only case reports have been published on the use of aflibercept [36].

Anecdotal reports of combined intravitreal anti-VEGF and corticosteroids in the treatment of IGS exist, but these are only case reports, not larger trials [37]. Therefore, it is difficult to judge the additional effect of those drugs compared to anti-VEGF therapy alone in IGS. 
Table 6. Results of the studies analyzing the efficacy of intravitreal anti-VEGF agents in the treatment of IGS that involved at least 10 cases and were published since 2000.

\begin{tabular}{|c|c|c|c|c|c|}
\hline No & Study & No of Eyes & Duration of CME & Study Design & Results \\
\hline 1 & Akay et al., 2020 [38] & $\begin{array}{l}\text { 59; } \\
\text { IVB: 22, IVR: } 19 \\
\text { IVA: } 18\end{array}$ & $\begin{array}{l}\text { Not stated; refractory to } \\
\text { topical treatment }\end{array}$ & $\begin{array}{l}\text { Retrospective, controlled } \\
\text { consecutive case series; } \\
\text { comparison of functional and } \\
\text { morphological results of } \\
\text { treatment among } 3 \text { agents at } \\
\quad 6 \text { months }\end{array}$ & $\begin{array}{c}\text { BCVA change: } \\
\text { IVB: } 0.96 \pm 0.18 \text { to } 0.23 \pm 0.19 \\
\text { IVR: } 0.89 \pm 0.23 \text { to } 0.19 \pm 0.18 \\
\text { IVA: } 0.94 \pm 0.22 \text { to } 0.21 \pm 0.08 \\
\text { CMT change: } \\
\text { IVB: } 555.5 \pm 238.5 \mathrm{~mm} \text { to } 213.5 \pm 21.1 \mathrm{~mm} \\
\text { IVR: } 553.5 \pm 125.5 \mathrm{~mm} \text { to } 226.6 \pm 18.1 \mathrm{~mm} \\
\text { IVA: } 540.0 \pm 64.5 \mathrm{~mm} \text { to } 227.7 \pm 39.5 \mathrm{~mm} \\
\text { No of injections: } \\
\text { IVB: } 1.8 \pm 0.7 \\
\text { IVR: } 2.0 \pm 0.6 \\
\text { IVA: } 1.8 \pm 0.7 \\
\text { No significant difference in results of } \\
\text { treatment and number of injections needed } \\
\text { among the three agents }\end{array}$ \\
\hline 2 & $\begin{array}{c}\text { Staurenghi et al., } 2018 \\
\text { [39] }\end{array}$ & 40 & 3 months and longer & $\begin{array}{l}\text { RCT; IVR } 0.5 \mathrm{mg} \text { for } \\
\text { IGS/aphakic eyes; one } \\
\text { injection of IVR at baseline, } \\
\text { then PRN regimen }\end{array}$ & $\begin{array}{l}\text { Letter gain at month } 2: 8.5 \text { in the IVR } \\
\text { group and } 4.1 \text { in the sham group } \\
\text { (significant difference) } \\
\text { At month 12: letter gain } 14.5 \text { vs. } 10.5 ; \\
\text { minor adverse events related to injection } \\
\text { (e.g., conjunctival hemorrhage) }\end{array}$ \\
\hline 3 & Arevalo et al., 2009 [40] & 36 & 3 months and longer & $\begin{array}{l}\text { Retrospective; at least } 1 \\
\text { injection of IVB in a dose of } \\
1.25 \text { or } 2.5 \mathrm{mg} \text {; follow up } \\
12 \text { months }\end{array}$ & $\begin{array}{l}\text { Improvement of BCVA of } 2 \text { ETDRS lines in } \\
72.2 \% \text {; none of the eyes worsened; mean } \\
\text { BCVA change from } 0.96 \text { to } 0.62 \text { logMAR; } \\
\text { CMT change from } 499.9 \text { to } 286.1 \mathrm{~mm} ; \\
\text { Mean no. of injections: } 2.7\end{array}$ \\
\hline 4 & Barone et al., 2009 [41] & 10 & $\begin{array}{l}\text { Mean } 17.5 \text { weeks } \\
\quad \text { (range } 11-24)\end{array}$ & $\begin{array}{l}\text { At least one IVB } 1.25 \mathrm{mg} ; \\
\text { evaluation of BCVA and CMT } \\
\text { at } 6 \text { months }\end{array}$ & $\begin{array}{l}\text { BCVA improvement in all eyes; Mean } \\
\text { BCVA change from } 20 / 80 \text { to 20/32; mean } \\
\text { CMT change from } 546.8 \text { to } 228.7 \mathrm{~mm}\end{array}$ \\
\hline 5 & Spitzer 2008 [42] & 16 & $\begin{array}{l}\text { Mean } 14 \text { weeks } \\
\text { (range 3-84 weeks) }\end{array}$ & $\begin{array}{l}\text { Retrospective case series; } 1.25 \\
\text { mg of IVB; evaluation of BCVA } \\
\text { change and CMT change }\end{array}$ & $\begin{array}{c}\text { BCVA improvement by } 2 \text { ETDRS letters in } \\
1 \text { eye, unchanged in } 12 \text { eyes and worsened } \\
\text { in } 2 \text { eyes; reduction in CMT by more than } \\
10 \% \text { in } 9 \text { eyes }\end{array}$ \\
\hline 6 & Arevalo et al., 2007 [43] & 25 & Not stated & $\begin{array}{l}\text { Retrospective; IVB of } 1.25 \text { or } \\
2.5 \mathrm{mg} \text {; mean follow up } \\
32 \text { weeks }\end{array}$ & $\begin{array}{l}\text { Improvement of BCVA of } 2 \text { ETDRS lines in } \\
71.4 \% \text {; none of the eyes worsened; mean } \\
\text { BCVA change from } 0.92 \text { to } 0.50 \text { logMAR; } \\
\text { CMT change from } 466.3 \text { to } 264.5 \mathrm{~mm} ; \\
28.6 \% \text { of eyes required a second injection, } \\
\text { and } 14.3 \% \text { required a third injection }\end{array}$ \\
\hline
\end{tabular}

RCT: randomized controlled trial; IGS: Irvine-Gass syndrome; CME: cystoid macular edema; IVB: intravitreal bevacizumab; IVR: intravitreal ranibizumab; IVA: intravitreal aflibercept; IVD: intravitreal dexamethasone implant (700 mg); BCVA: best-corrected visual acuity; CMT: central macular thickness.

\subsection{Subthreshold Micropulse Laser (SML)}

A photostimulation process with repetitive short pulses delivered at a subthreshold mode allows foveal treatment with no damage compared to conventional laser treatments. The benefits of SML in the treatment of different macular disorders such as central serous chorioretinopathy (CSC), diabetic macular edema (DME), and macular edema secondary to retinal vein occlusion (RVO) were shown in many studies [44,45].

In 2020, Verdina et al. published the first results of the treatment of refractory postoperative CME with subthreshold micropulse yellow laser in 10 eyes of 10 patients [46]. Five eyes of five patients had Irvine-Gass syndrome. A retrospective analysis showed improvement of BCVA and CMT in all patients, and the effects were maintained through $1,2,3$, and 6 months. The treatment used a $577 \mathrm{~nm}$ subliminal laser photo-stimulation treatment with $7 \times 7$ grids with confluent spots and a $5 \%$ duty cycle. Treatment was targeted at whole edematous retina, including the foveal center. The study demonstrated complete resolution of retinal edema and improvement of BCVA in all patients with no side effects. The mean number of laser treatments was 1.3.

\subsection{Laser Photocoagulation (LPC)}

No studies of LPC in IGS published after 2000 were found in the PUBMED database. Previous studies reported a beneficial effect of modified GRID protocol for IGS; however, these were not controlled studies [47]. 


\subsection{Other Treatments}

Interferon alfa was administered for IGS in a small case series of four eyes refractory to topical treatment [48]. A 3 million IU/day dose was injected subcutaneously for 4 weeks and tapered thereafter. Improvement was achieved in three cases without any side effects. Topical treatment of chronic refractory IGS with interferon alfa was also reported in a single case with spectacular visual improvement from 20/100 to 20/25 [49].

IGS was also treated by adalimumab (Humira). No significant improvement after such therapy was achieved in a small case series of five eyes [50].

\section{Discussion}

The excellent results of modern cataract surgery set patient expectations very high, and persistent CME after uneventful cataract surgery may significantly affect patient outcomes and satisfaction [51]. Irvine-Gass syndrome is a common complication of uneventful cataract surgery, which resolves spontaneously in most cases but may persist, causing visual deterioration and patient dissatisfaction $[4,6,7]$. As has been emphasized in many previous reviews and studies, no homogenous recommendations for the treatment of IVG exist [52-55]. The lack of randomized controlled trials assessing the effectiveness of available therapeutic modalities results in many different approaches, often based on individual judgment and clinical experience but not hard evidence. Our analysis focused on the papers published in this century, as this is the time when intravitreal treatments such as anti-VEGF or intravitreal corticosteroids were introduced and revolutionized the management of various ophthalmic diseases. Therefore, we sought to compare conservative treatments to those modern therapeutic modalities.

Presented studies published since $2000^{t}$ in general show favorable results of the treatment of IGS with topical NSAIDs alone or in combination with periocular or intravitreal steroids as well as intravitreal anti-VEGF agents. Those treatments should be considered, weighing both the potential for improving BCVA and the invasive character of the treatment and the possibility of complications.

As IGS resolves spontaneously in most cases, that possibility must be considered before administering invasive therapy. Therefore, the timing of the application of different forms of treatment should be carefully considered with non-invasive therapies used as the first line (e.g., topical treatment) and invasive procedures (e.g., intraocular injections) usually reserved for non-responsive cases.

NSAIDs administered topically such as via eye drops are FDA-approved drugs for use as anti-inflammatory, antipyretic, and analgesic agents. Their main mechanism of action is the inhibition of the enzyme cyclooxygenase (COX). Cyclooxygenase is required to convert arachidonic acid into thromboxanes, prostaglandins, and prostacyclin. Prostaglandins play an important role in vasodilatation [56]. The use of NSAIDs in the postoperative management of patients undergoing cataract surgery has become a standard of care $[57,58]$. Routine use of anti-inflammatory eye drops following cataract surgery is highly effective in reducing post-surgical inflammation and the incidence of CME [59]; however, their role in the treatment of CME has not been studied widely. Topical NSAIDs remain a first-line therapy of IGS, and although their use has shown to be beneficial in several studies, they have shown no clear effect in other studies [58]. Our search revealed only a few modern studies that analyze the effects of NSAID in the treatment of IGS, none of which is an RCT. One older study showed significant visual and morphological improvements after administration of topical NSAID in acute cases, which are usually defined as lasting less than 3 months [18]. However, most recent studies show only moderate improvement after treatment of IGS with only topical NSAID [12,13].

Functional and morphological results are reported to be better after intravitreal dexamethasone [13]. Adding the effect of nepafenac was reported in one study that analyzed the combination of IVB and NSAID [16]. NSAIDs are also used in combined therapy with topical corticosteroids or oral CAIs, but available data on the combined treatment of CME are very limited. Nevertheless, the off-label use of acetazolamide, a carbonic anhydrase 
inhibitor, in IGS is a common practice as a first- or second-line therapy. Acetazolamide increases the retinal pigment epithelium pump function by inhibiting carbonic anhydrase and is thought to decrease intraretinal fluid $[11,60]$. Dosage varies among studies from $250 \mathrm{mg}$ once a day to TID. Many authors state that the combination of oral acetazolamide with topical NSAIDs is shown to be highly effective [20,61,62]. Our search revealed only two papers analyzing the additional effect of CAI compared to NSAID-only treatment of IGS, both on relatively small samples (14-15 eyes). Both papers favor the use of CAI in combination therapy for IGS; however, such limited data make it impossible to build strong recommendations for the use of this treatment regimen.

Corticosteroids remain a viable therapeutic option in the treatment of CME, including IGS. Corticosteroids block the release of arachidonic acid, impact the production of interleukins and VEGF, and interrupt the inflammatory cascade. Several routes of administration, such as topical, periocular, and intravitreal, are available. At the same time, current data on a combination treatment of topical NSAID with topical corticosteroids are scarce and not convincing $[21,22]$. A conclusion on the beneficial effect of the addition of topical corticosteroids to the treatment of IGS cannot be made based on available research. Nevertheless, topical corticosteroids are widely used in the treatment of Irvine-Gass syndrome, usually in combination with topical NSAIDs and oral CAIs. An accurate assessment of the role of topical corticosteroids alone in the treatment of IGS is not currently possible.

Periocular or intravitreal corticosteroids serve as an option in refractory cases of IGS [63]. Sub-tenon or retrobulbar injections of corticosteroids had been used widely for persistent CME before the advent of an officially registered intravitreal dexamethasone implant $\left(\right.$ OZURDEX $\left.{ }^{\circledR}\right)$. Early in 1997, Thach and his group showed VA improvement after 12 repeated corticosteroid injections in a series of 31 patients with chronic CME [64]. Our search revealed three recent studies (2018-2021) that showed significant visual improvement after STT in refractory cases of IGS. STT remains a cost-effective therapy, and its application sub-tenon does not bear the risk of intraocular inflammation possible after intravitreal application. A recent study by Kuley did not show an advantage of intravitreal versus sub-tenon administration of triamcinolone [23]. It must be emphasized, though, that the use of triamcinolone acetonide remains off-label. Intravitreal corticosteroids have consequently been used for chronic or refractory cases, lasting longer than 3 months, with significant letter gains and minor adverse effects [31-35]. Before the dexamethasone implant was introduced, triamcinolone acetonide was tested in a few larger and smaller studies, proving its efficacy in improving macular morphology and function in IGS [33,35,65-67]. Later studies show significant improvements after IVD administration without serious side effects $[27,29-32,34]$. The most recent large retrospective study from 2020 highlighted the benefits of early intervention and reported significantly larger visual gains when IVD was administered within 4 weeks of diagnosis [27]. This approach is not a common practice due to the invasive character of the procedure and the possibility of effective treatment with only topical NSAIDs. Further comparative studies are needed to support the results of that paper.

Vascular endothelial growth factors play central roles in the regulation of angiogenesis and lymphangiogenesis and they regulate endothelial cell proliferation, migration, vascular permeability, secretion, and other endothelial functions. The revolutionary role of antiVEGF in treating ophthalmic conditions such as neovascularization and macular edema due to DME or ME in RVO was a milestone. The VEGF family plays a major role in angiogenesis, inflammation, and capillary permeability; thus, its potential in treating CME was studied. However, the role of anti-VEGF treatment in CME remains unclear. Anti-VEGF injections remain an alternative in unresponsive cases, but their use in IGS requires further randomized research. Our search revealed a few quality studies that show significant improvements after the use of anti-VEGF medication in IGS, but RCTs are missing. Despite that, clinical practice and the universality of that procedure make it a solid treatment modality in refractory IGS. 
Non-damaging laser therapy, such as SML, remains an interesting therapeutic option. To date, just a few papers report its efficacy in IGS. Considering its non-damaging character, lack of side effects, and low cost, it may be considered as an alternative to more invasive treatment modalities. Further studies are needed to provide treatment guidelines for SML.

\section{Practical Considerations and Conclusions}

This review aimed to provide a basis for modern recommendations for treating pseudophakic macular edema or Irvine-Gass syndrome. The available published material does not provide convincing data to build such guidelines. Therefore, theoretical background, clinical experience, and safety of the procedure must determine the choice of treatment in this clinical entity. Common practice is to start therapy with a topical NSAID, which is a simple and non-invasive treatment modality. This approach is supported by epidemiological and clinical research that provides data on the possibility of spontaneous resolution of CME and improvement after topical therapy [68]. Larger clinical trials have not shown that using a combination of topical NSAID and topical corticosteroids and/or oral CAI is superior to topical NSAID alone.

What remains unclear is the timing of application of invasive therapies-periocular or intravitreal injections-once topical treatment is not effective. Refractory pseudophakic macular edema is not precisely defined according to its duration, but usually authors employ periocular or intravitreal treatment in cases lasting longer than three months. The efficacy and safety of intravitreal or periocular injections with corticosteroids or antiVEGF agents have been confirmed in many studies. Still, its invasive nature and rare but potentially serious complications must be considered. Patients who resist intravitreal or periocular treatment might be offered therapy with subthreshold micropulse laser. Recent publications on the use of SML show promise. Low complication rates, cost-effectiveness, and repeatability are clear advantages of this treatment modality.

Our search revealed publications that show possible options for the treatment of IGS. Methodology and randomization in presented trials may be discussed; what remains as their common feature is the visual deficit reported in most cases of longstanding CME, even after successful treatment. Therefore, in view of results of a recent large study from Sharma et al. [27] that proves better functional and morphological results with early application of intravitreal steroids, that therapeutic option for short-standing pseudophakic CME should be examined with care in future research.

Author Contributions: Conceptualization: M.O. and M.G.; Methodology: M.G., Investigation: M.O. and M.G., writing: M.O. and M.G., supervision: M.G. All authors have read and agreed to the published version of the manuscript.

Funding: This research received no external funding.

Institutional Review Board Statement: Not applicable.

Informed Consent Statement: Not applicable.

Data Availability Statement: Not applicable.

Conflicts of Interest: The authors declare no conflict of interest.

\section{References}

1. Grzybowski, A.; Sikorski, B.L.; Ascano, F.J.; Huerva, V. Pseudophakic cystoid macular edema. Clin. Interv. Aging 2016, 11, 1221-1229. [CrossRef] [PubMed]

2. Irvine, S.R. A newly defined vitreous syndrome following cataract surgery. Am. J. Ophthalmol. 1953, 36, 599-619. [CrossRef]

3. Gass, J.D.; Norton, E.W. Cystoid macular edema and papilledema following cataract extraction. A fluorescein fundoscopic and angiographic study. Arch. Ophthalmol. 1966, 76, 646-661. [CrossRef] [PubMed]

4. Henderson, B.A.; Kim, J.Y.; Ament, C.S.; Ferrufino-Ponce, Z.K.; Grabowska, A.; Cremers, S.L. Clinical pseudophakic cystoid macular edema. Risk factors for development and duration after treatment. J. Cataract Refract. Surg. 2007, 33, 1550-1558. [CrossRef] [PubMed] 
5. Hunter, A.A.; Modjtahedi, S.P.; Long, K.; Zawadzki, R.; Chin, E.K.; Caspar, J.J.; Morse, L.S.; Telander, D.G. Improving visual outcomes by preserving outer retina morphology in eyes with resolved pseudophakic cystoid macular edema. J. Cataract Refract. Surg. 2014, 40, 626-631. [CrossRef]

6. Flach, A.J. The incidence, pathogenesis and treatment of cystoid macular edema following cataract surgery. Trans. Am. Ophthalmol. Soc. 1998, 96, 557-634.

7. Perente, I.; Utine, C.A.; Ozturker, C.; Cakir, M.; Kaya, V.; Eren, H.; Kapran, Z.; Yilmaz, O.F. Evaluation of macular changes after uncomplicated phacoemulsification surgery by optical coherence tomography. Curr. Eye Res. 2007, 32, 241-247. [CrossRef]

8. Ursell, P.G.; Spalton, D.J.; Whitcup, S.M.; Nussenblatt, R.B. Cystoid macular edema after phacoemulsification: Relationship to blood-aqueous barrier damage and visual acuity. J. Cataract Refract. Surg. 1999, 25, 1492-1497. [CrossRef]

9. Shelsta, H.N.; Jampol, L.M. Pharmacologic therapy of pseudophakic cystoid macular edema: 2010 update. Retina 2011, 31, 4-12. [CrossRef] [PubMed]

10. Smith, R.T.; Campbell, C.J.; Koester, C.J.; Trokel, S.; Anderson, A. The barrier function in extracapsular cataract surgery. Ophthalmology 1990, 97. [CrossRef]

11. Benitah, N.R.; Arroyo, J.G. Pseudophakic cystoid macular edema. Int. Ophthalmol. Clin. 2010, 50, 139-153. [CrossRef]

12. Giarmoukakis, A.K.; Blazaki, S.V.; Bontzos, G.C.; Plaka, A.D.; Seliniotakis, K.N.; Ioannidi, L.D.; Tsilimbaris, M.K. Efficacy of topical nepafenac $0.3 \%$ in the management of postoperative cystoid macular edema. Ther. Clin. Risk Manag. 2020, 16, 1067-1074. [CrossRef]

13. Guclu, H.; Gurlu, V.P. Comparison of topical nepafenac $0.1 \%$ with intravitreal dexamethasone implant for the treatment of Irvine-Gass syndrome. Int. J. Ophthalmol. 2019, 12, 258-267. [CrossRef] [PubMed]

14. Sengupta, S.; Vasavada, D.; Pan, U.; Sindal, M. Factors predicting response of pseudophakic cystoid macular edema to topical steroids and nepafenac. Indian J. Ophthalmol. 2018, 66, 827-830. [CrossRef] [PubMed]

15. Yüksel, B.; Uzunel, U.D.; Kerci, S.G.; Sağban, L.; Kusbeci, T.; Örsel, T. Comparison of subtenon triamcinolone acetonide injection with topical nepafenac for the treatment of pseudophakic cystoid macular edema. Ocul. Immunol. Inflamm. 2016, 25, 513-519. [CrossRef]

16. Warren, K.A.; Bahrani, H.; Fox, J.E. NSAIDs in combination therapy for the treatment of chronic pseudophakic cystoid macular edema. Retina 2010, 30, 260-266. [CrossRef] [PubMed]

17. Hariprasad, S.M.; Akduman, L.; Clever, J.A.; Ober, M.; Recchia, F.M.; Mieler, W.F. Treatment of cystoid macular edema with the new-generation NSAID nepafenac 0.1\%. Clin. Ophthalmol. 2009, 3, 147-154. [CrossRef]

18. Rho, D.S. Treatment of acute pseudophakic cystoid macular edema: Diclofenac versus ketorolac. J. Cataract Refract. Surg. 2003, 29, 2378-2384. [CrossRef]

19. Curković, T.; Vukojević, N.; Bućan, K. Treatment of pseudophakic cystoid macular oedema. Coll. Antropol. 2005, $103-105$.

20. Catier, A.; Tadayoni, R.; Massin, P.; Gaudric, A. Intérêt de l'acétazolamide associé aux anti-inflammatoires dans le traitement de l'oedème maculaire postopératoire (Advantages of acetazolamide associated with anti-inflammatory medications in postoperative treatment of macular edema). J. Fr. Ophtalmol. 2005, 28, 1027-1031. [CrossRef]

21. Heier, J.S.; Topping, T.M.; Baumann, W.; Dirks, M.S.; Chern, S. Ketorolac versus prednisolone versus combination therapy in the treatment of acute pseudophakic cystoid macular edema. Ophthalmology 2000, 107, 2034-2038. [CrossRef]

22. Singal, N.; Hopkins, J. Pseudophakic cystoid macular edema: Ketorolac alone vs. ketorolac plus prednisolone. Can. J. Ophthalmol. 2004, 39, 245-250. [CrossRef]

23. Kuley, B.; Storey, P.P.; Wibbelsman, T.D.; Pancholy, M.; Zhang, Q.; Sharpe, J.; Bello, N.; Obeid, A.; Regillo, C.; Kaiser, R.S.; et al. Resolution of pseudophakic cystoid macular edema: $2 \mathrm{mg}$ intravitreal triamcinolone acetonide versus $40 \mathrm{mg}$ posterior sub-tenon triamcinolone acetonide. Curr. Eye Res. 2021, 1-7. [CrossRef]

24. Erden, B.; Çakır, A.; Aslan, A.C.; Bölükbaşı, S.; Elçioğlu, M.N. The efficacy of posterior subtenon triamcinolone acetonide injection in treatment of irvine-gass syndrome. Ocul. Immunol. Inflamm. 2019, 27, 1235-1241. [CrossRef]

25. Tsai, M.-J.; Yang, C.-M.; Hsieh, Y.-T. Posterior subtenon injection of triamcinolone acetonide for pseudophakic cystoid macular oedema. Acta Ophthalmol. 2016, 96, e891-e893. [CrossRef]

26. Benhamou, N.; Massin, P.; Haouchine, B.; Audren, F.; Tadayoni, R.; Gaudric, A. Intravitreal triamcinolone for refractory pseudophakic macular edema. Am. J. Ophthalmol. 2003, 135, 246-249. [CrossRef]

27. Sharma, A.; Bandello, F.; Loewenstein, A.; Kuppermann, B.D.; Lanzetta, P.; Zur, D.; Hilely, A.; Iglicki, M.; Veritti, D.; Wang, A.; et al. Current role of intravitreal injections in Irvine Gass syndrome-CRIIG study. Int. Ophthalmol. 2020, 40, 3067-3075. [CrossRef] [PubMed]

28. Marques, J.H.; Abreu, A.C.; Silva, N.; Meireles, A.; Pessoa, B.; Melo Beirão, J. Fluocinolone acetonide 0.19 mg implant in patients with cystoid macular edema due to Irvine-Gass syndrome. Int. Med. Case Rep. J. 2021, 26, 127-132. [CrossRef] [PubMed]

29. Altintas, A.G.K.; Ilhan, C. Intravitreal dexamethasone implantation in intravitreal bevacizumab treatment-resistant pseudophakic cystoid macular edema. Korean J. Ophthalmol. 2019, 33, 259-266. [CrossRef] [PubMed]

30. Bellocq, D.; Pierre-Kahn, V.; Matonti, F.; Burillon, C.; Voirin, N.; Dot, C.; Akesbi, J.; Milazzo, S.; Baillif, S.; Soler, V.; et al. Effectiveness and safety of dexamethasone implants for postsurgical macular oedema including Irvine-Gass syndrome: The EPISODIC-2 study. Br. J. Ophthalmol. 2016, 101, 333-341. [CrossRef] [PubMed] 
31. Mayer, W.J.; Kurz, S.; Wolf, A.; Kook, D.; Kreutzer, T.; Kampik, A.; Priglinger, S.; Haritoglou, C. Dexamethasone implant as an effective treatment option for macular edema due to Irvine-Gass syndrome. J. Cataract Refract. Surg. 2015, 41, 1954-1961. [CrossRef] [PubMed]

32. Al Zamil, W.M. Short-term safety and efficacy of intravitreal 0.7-mg dexamethasone implants for pseudophakic cystoid macular edema. Saudi J. Ophthalmol. 2014, 29, 130-134. [CrossRef]

33. Sevim, M.; Sanisoglu, H.; Türkyılmaz, K. Intravitreal triamcinolone acetonide versus pars plana vitrectomy for pseudophakic cystoid macular edema. Curr. Eye Res. 2012, 37, 1165-1170. [CrossRef]

34. Williams, G.A.; Haller, J.A.; Kuppermann, B.D.; Blumenkranz, M.S.; Weinberg, D.V.; Chou, C.; Whitcup, S.M. Dexamethasone DDS phase II study group. Dexamethasone posterior-segment drug delivery system in the treatment of macular edema resulting from uveitis or Irvine-Gass syndrome. Am. J. Ophthalmol. 2009, 147, 1048-1054. [CrossRef]

35. Koutsandrea, C.; Moschos, M.M.; Brouzas, D.; Loukianou, E.; Apostolopoulos, M.; Moschos, M. Intraocular triamcinolone acetonide for pseudophakic cystoid macular edema: Optical coherence tomography and multifocal electroretinography study. Retina 2007, 27, 159-164. [CrossRef] [PubMed]

36. Lin, C.J.; Tsai, Y.Y. Use of aflibercept for the management of refractory pseudophakic macular edema in Irvine-Gass syndrome nad literature review. Retin. Cases Brief. Rep. 2018, 12, 59-62. [CrossRef]

37. Fenicia, V.; Balestrieri, M.; Perdicchi, A.; Enrici, M.M.; Fave, M.D.; Recupero, S.M. Intravitreal injection of dexamethasone implant and ranibizumab in cystoid macular edema in the course of Irvine-Gass syndrome. Case Rep. Ophthalmol. 2014, 5, 243-248. [CrossRef]

38. Akay, F.; Isik, M.U.; Akmaz, B. Comparison of intravitreal anti-vascular endothelial growth factor agents and treatment results in Irvine-Gass syndrome. Int. J. Ophthalmol. 2020, 13, 1586-1591. [CrossRef]

39. Staurenghi, G.; Lai, T.Y.Y.; Mitchell, P.; Wolf, S.; Wenzel, A.; Li, J.; Bhaumik, A.; Hykin, P.G.; PROMETHEUS Study Group. Efficacy and safety of ranibizumab $0.5 \mathrm{mg}$ for the treatment of macular edema resulting from uncommon causes: Twelve-month findings from prometheus. Ophthalmology 2018, 125, 850-862. [CrossRef] [PubMed]

40. Arevalo, J.F.; Maia, M.; Garcia-Amaris, R.A.; Roca, J.A.; Sanchez, J.G.; Berrocal, M.H.; Wu, L. Intravitreal bevacizumab for refractory pseudophakic cystoid macular edema: The Pan-American collaborative retina study group results. Ophthalmology 2009, 116, 1481.e1-1487.e1. [CrossRef]

41. Barone, A.; Russo, V.; Prascina, F.; Noci, N.D. Short-term safety and efficacy of intravitreal bevacizumab for pseudophakic cystoid macular edema. Retina 2009, 29, 33-37. [CrossRef]

42. Spitzer, M.S.; Ziemssen, F.; Yoeruek, E.; Petermeier, K.; Aisenbrey, S.; Szurman, P. Efficacy of intravitreal bevacizumab in treating postoperative pseudophakic cystoid macular edema. J. Cataract Refract. Surg. 2008, 34, 70-75. [CrossRef]

43. Arevalo, J.F.; Garcia-Amaris, R.A.; Roca, J.A.; Sanchez, J.G.; Wu, L.; Berrocal, M.H.; Maia, M. Primary intravitreal bevacizumab for the management of pseudophakic cystoid macular edema: Pilot study of the Pan-American collaborative retina study Group. J. Cataract Refract. Surg. 2007, 339120, 2098-3105. [CrossRef] [PubMed]

44. Gawęcki, M. Micropulse laser treatment of retinal diseases. J. Clin. Med. 2019, 8, 242. [CrossRef]

45. Gawęcki, M.; Jaszczuk-Maciejewska, A.; Jurska-Jaśko, A.; Kneba, M.; Grzybowski, A. Transfoveal micropulse laser treatment of central serous chorioretinopathy within six months of disease onset. J. Clin. Med. 2019, 8, 1398. [CrossRef] [PubMed]

46. Verdina, T.; D'Aloisio, R.; Lazzerini, A.; Ferrari, C.; Valerio, E.; Mastropasqua, R.; Cavallini, G.M. The role of subthreshold micropulse yellow laser as an alternative option for the treatment of refractory postoperative cystoid macular edema. J. Clin. Med. 2020, 9, 1066. [CrossRef]

47. Lardenoye, C.W.; van Schooneveld, M.J.; Frits Treffers, W.; Rothova, A. Grid laser photocoagulation for macular oedema in uveitis or the Irvine-Gass syndrome. Br. J. Ophthalmol. 1998, 82, 1013-1016. [CrossRef]

48. Deuter, C.M.E.; Gelisken, F.; Stübiger, N.; Zierhut, M.; Doycheva, D. Successful treatment of chronic pseudophakic macular edema (Irvine-Gass syndrome) with interferon alpha: A report of three cases. Ocul. Immunol. Inflamm. 2011, 19, 216-218. [CrossRef] [PubMed]

49. Maleki, A.; Aghaei, H.; Lee, S. Topical interferon alpha $2 \mathrm{~b}$ in the treatment of refractory pseudophakic cystoid macular edema. Am. J. Ophthalmol. Case Rep. 2018, 10, 203-205. [CrossRef]

50. Farvardin, M.; Namvar, E.; Sanie-Jahromi, F.; Johari, M.K. The effects of intravitreal adalimumab injection on pseudophakic macular edema. BMC Res. Notes 2020, 13,1-4. [CrossRef]

51. Gawęcki, M.; Grzybowski, A. Diplopia as the complication of cataract surgery. J. Ophthalmol. 2016, 2016, 1-6. [CrossRef]

52. Tsangaridou, M.-A.; Grzybowski, A.; Gundlach, E.; Pleyer, U. Controversies in NSAIDs use in cataract surgery. Curr. Pharm. Des. 2015, 21, 4707-4717. [CrossRef]

53. Grzybowski, A.; Kanclerz, P. Controversies on the use of nonsteroidal antiinflammatory drugs and steroids in pseudophakic cystoid macular edema prophylaxis. J. Cataract Refract. Surg. 2019, 45, 1848. [PubMed]

54. Guo, S.; Patel, S.; Baumrind, B.; Johnson, K.; Levinsohn, D.; Marcus, E.; Tannen, B.; Roy, M.; Bhagat, N.; Zarbin, M. Management of pseudophakic cystoid macular edema. Surv. Ophthalmol. 2015, 60, 123-137. [CrossRef]

55. Yonekawa, Y.; Kim, I.K. Pseudophakic cystoid macular edema. Curr. Opin. Ophthalmol. 2012, 23, 26-32. [CrossRef] [PubMed]

56. Vane, J.R. Inhibition of prostaglandin synthesis as a mechanism of action for aspirin-like drugs. Nat. New Biol. 1971, 231, 232-235. [CrossRef] [PubMed] 
57. Brandsdorfer, A.; Patel, S.H.; Chuck, R.S. The role of perioperative nonsteroidal anti-inflammatory drugs use in cataract surgery. Curr. Opin. Ophthalmol. 2019, 30, 44-49. [CrossRef] [PubMed]

58. Lim, B.X.; Lim, C.H.; Lim, D.K.; Evans, J.R.; Bunce, C.; Wormald, R. Prophylactic non-steroidal anti-inflammatory drugs for the prevention of macular oedema after cataract surgery. Cochrane Database Syst. Rev. 2016. [CrossRef] [PubMed]

59. Rossetti, L.; Chaudhuri, J.; Dickersin, K. Medical prophylaxis and treatment of cystoid macular edema after cataract surgery: The results of a meta-analysis. Ophthalmology 1998, 105, 397-405. [CrossRef]

60. Marmor, M.F.; Maack, T. Enhancement of retinal adhesion and sub- retinal fluid resorption by acetazolamide. Invest. Ophthalmol. Vis. Sci. 1982, 23, 121-124.

61. Cox, S.N.; Hay, E.; Bird, A.C. Treatment of chronic macular edema with acetazolamide. Arch. Ophthalmol. 1988, 106, 1190-1195. [CrossRef]

62. Weene, L. Cystoid macular edema after scleral buckling responsive to acetazolamide. Ann. Ophthalmol. 1992, 24.

63. Zur, D.; Loewenstein, A. Postsurgical cystoid macular edema. Dev. Ophthalmol. 2017, 58, 178-190. [CrossRef] [PubMed]

64. Thach, A.B.; Dugel, P.U.; Flindall, R.J.; Sipperley, J.O.; Sneed, S.R. A Comparison of retrobulbar versus sub-tenon's corticosteroid therapy for cystoid macular edema refractory to topical medications. Ophthalmology 1997, 104, 2003-2008. [CrossRef]

65. Boscia, F.; Furino, C.; Dammacco, R.; Ferreri, P.; Sborgia, L. Intravitreal triamcinolone acetonide in refractory pseudophakic cystoid macular edema: Functional and anatomic results. Eur. J. Ophthalmol. 2005, 15, 89-95. [CrossRef] [PubMed]

66. Jonas, J.B.; Kreissig, I.; Degenring, R.F. Intravitreal triamcinolone acetonide for pseudophakic cystoid macular edema. Am. J. Ophthalmol. 2003, 136, 384-386. [CrossRef]

67. Conway, M.D.; Canakis, C.; Livir-Rallatos, C.; Peyman, G.A. Intravitreal triamcinolone acetonide for refractory chronic pseudophakic cystoid macular edema. J. Cataract Refract. Surg. 2003, 29, 27-33. [CrossRef]

68. Zur, D.; Fischer, N.; Tufail, A.; Monés, J.; Loewenstein, A. Postsurgical cystoid macular edema. Eur. J. Ophthalmol. 2011, 21, 62-68. [CrossRef] 